\title{
A syndrome of sleep apnea in morbid obesity
}

\author{
Alberto Herrejón Silvestre*, Ignacio Inchaurraga Alvarez, Eduardo González Constan, Carlos Morillas Ariño, Rocio Royo Taberner, and \\ Antonio Hernández Mijares
}

Pneumology and Endocrinology Services, University Hospital Dr Peset, Valencia, Spain

\begin{abstract}
Abbreviations : NP: nocturnal pulse oximetry, BMI: body mass index, ESS: Epworth sleepiness scale, SBP: Systolic blood pressure $(\mathrm{mmHg})$, DAP: Diastolic blood pressure $(\mathrm{mmHg})$, LM: Lean mass (Kg), FM: Fat mass (Kg), \% BF: Percentage of body fat, Glyc: Basal glycemia (mg/dl), Ins: Basal Insulin (IU), Chol: Cholesterol (mg/dl), Tgc: Triglycerides (mg/dl), DLCO: Diffusion of CO (\%), KCO: DLCO/ alveolar ventilation (\%), PIM: Inspiratory mouth pressure at residual volume $\left(\mathrm{cm} \mathrm{H}_{2} \mathrm{O}\right)$, PEM: Expiratory pressure in the mouth at total lung capacity $\left(\mathrm{cmH}_{2} \mathrm{O}\right), \mathrm{PO}_{2}$ and $\mathrm{PCO}_{2}$ : Partial pressures in arterial blood of $\mathrm{O}_{2}$ and $\mathrm{CO}_{2}(\mathrm{mmHg}), \mathrm{SO}_{2}: \mathrm{O}_{2}$ arterial saturation (\%), Neck: perimeter of neck $(\mathrm{cm}), \mathrm{W} / \mathrm{H}$ : waist/hip index, LM: Lean mass $(\mathrm{Kg}), \%$ BF: Percentage of body fat (\%), FVC: forced vital capacity (\%), $\mathrm{FEV}_{1}$ : Forced expiratory volume in the first second (\%), TLC: Total lung capacity (\%), FRC: Functional residual capacity (\%), RV: Residual volume (\%), $\mathrm{PO}_{2}$ : Blood pressure of oxygen $(\mathrm{mmHg}), \mathrm{PCO}_{2}$ : Blood pressure of carbon dioxide $(\mathrm{mmHg}), \mathrm{SO}_{2}$ : arterial oxygen saturation (\%), Min $\mathrm{SO}_{2}$ : Minimum night oxygen saturation (\%), Noct $\mathrm{SO}_{2}$ : Basal nocturnal oxygen saturation (\%), ODI: Number of nocturnal oxygen desaturations greater than $4 \%$ per hour, Insp Pres: Continuous inspiratory pressure in the airway $\left(\mathrm{cm} \mathrm{H}_{2} \mathrm{O}\right)$, Expi Pres: Continuous expiratory pressure in the airway $\left(\mathrm{cmH}_{2} \mathrm{O}\right)$.
\end{abstract}

\section{Introduction}

Sleep Apnea Syndrome (SAS) is a pathology of high prevalence in the general population, which affects men predominantly, increases with age and is frequently associated with obesity $[1,2]$. The importance of SAS is due to its high morbidity (arterial hypertension, arrhythmias, myocardial infarction and stroke) [3], which causes higher mortality [4].

Obesity has important cardiovascular consequences, with arterial hypertension and affectation of myocardial function [5]. From the respiratory point of view, two syndromes have been associated: Alveolar hypoventilation syndrome and SA [6]. In morbid obesity (MO), the incidence of SAS is 12 to 30 times higher than in the general population [7] and it is recommended that sleep studies be performed routinely in this circumstance [8]. The presence of MO and SAS have a high risk of sudden cardiovascular death, even in the absence of other conventional risk factors [9].

The incidence of SAS in MO varies according to sex with a clear predominance of men [10], with the accumulation of visceral fat being an important risk factor for SAS in obese subjects [11]. However, there are few studies in patients with $\mathrm{MO}$ in which comparisons are established by sex or by type of obesity, and the number of patients included in the study is small.

In this study we evaluated, in a large sample of patients with $\mathrm{MO}$, the prevalence of respiratory disorders during sleep and the influence of sex and the type of obesity in them.

\section{Material and methods}

At weight $40 \mathrm{~kg} / \mathrm{m}^{2}$ (the hospital level, patients with no BMI (body mass index) in kilograms/height in meters squared) were selected, who were to be submitted to a very low calorie diet $(450 \mathrm{Kcal} /$ day) for weight reduction and the following parameters were determined, grouped by sex: age (years), weight $(\mathrm{kg})$, height $(\mathrm{cm})$, BMI $\left(\mathrm{kg} / \mathrm{m}^{2}\right)$, neck circumference, waist at the level of the navel $(\mathrm{cm})$ and hip at the level of major trochanters $(\mathrm{cm})$, waist/hip index $(\mathrm{W} / \mathrm{H})$. Central or android type obesity was considered with a $\mathrm{W} / \mathrm{H}$ index $>1$ in males and $>0.9$ in females [12]. Systolic blood pressure (SBP) and diastolic blood pressure $(\mathrm{mmHg})$ were measured. Body composition was calculated by means of bioelectrical impedanciometry (Holtein), determining the lean mass $(\mathrm{kg})$, fat mass (FM) (kg) and the percentage of body fat (\% BF). Hematocrit $(\mathrm{Ht})$, basal glucose $(\mathrm{mg} / \mathrm{dl})$, basal insulin (IU), total cholesterol (TC), triglycerides (TGC) and HDL, LDL and VLDL cholesterol fractions).

\section{At the respiratory functional level, we performed:}

1. Arterial blood pressure (ABL 300 from Radiometer Co, Copenhagen), recording $\mathrm{pH}, \mathrm{PO}_{2}(\mathrm{mmHg}), \mathrm{PCO}_{2}(\mathrm{mmHg})$ and saturation of $\mathrm{O}_{2}\left(\mathrm{SO}_{2}\right)(\%)$.

2. Flow-volume curve (system 2800 pneumatic catheter from SensorMedics Corporation, California 1984), recording forced vital capacity (FVC), forced expiratory volume in the first second $\left(\mathrm{FEV}_{1}\right)$ (liters) and $\mathrm{FEV}_{1} / \mathrm{FVC}$.

3. Static volumes by body plethysmography (Body Box 2800 by SensorMedics), measuring total lung capacity (TLC) (liters), residual volume (RV) (liters) and functional residual capacity (FRC) (liters).

4. By the unique breathing method (SensorMedics 2100 Equipment), the diffusion capacity of CO (DLCO) (mmol/kPa.min), as recommended by ATS [13].

5. Maximum respiratory pressures were determined in the mouth with nasal occlusion by a portable digital pressure gauge (MicroMPM from SensorMedics, Brethoven, Netherland), according to the method of Black and Hyatt [14]. Maximal expiratory pressure (MEP) at TLC level in $\mathrm{cm} \mathrm{H}_{2} \mathrm{O}$, with hands on cheek were measured to minimize the effect of buccinators and maximal inspiratory pressure (MIP) in $\mathrm{cm} \mathrm{H}_{2} \mathrm{O}$, with a $1 \mathrm{~mm}$ to avoid the suction effect.

Correspondence to: Alberto Herrejón Silvestre, Pneumology Service. University Hospital Dr Peset, Avda, Gaspar, Aguilar 90, 46017-Valencia, Spain, Fax: 0034961622438; E-mail: herrejon_alb@gva.es.

Received: May 26, 2017; Accepted: June 23, 2017; Published: June 26, 2017 
The spirometric, plethysmographic and diffusion values of $\mathrm{CO}$ were calculated as a percentage of the theoretical, according to the ECSC tables [15], while in the maximum respiratory pressures the tables were used for the Mediterranean population of Morales el al [16].

Daytime somnolence was assessed using the Epworth scale [17], translated and validated in Spanish [18]. Nocturnal pulse oximetry (NP) [19] was performed with a continuous recording, assessing falls in $\mathrm{SO}_{2}$, greater than $4 \%$ (ODI), being the pathological record with more than 10 ODI per hour. The minimum night $\mathrm{SO}_{2}$ was recorded. Positive double airway pressure (DPAP) was placed in the nasal mask until normalization of NP, recording inspiratory pressures $\left(\mathrm{cm} \mathrm{H}_{2} \mathrm{O}\right)$, expiratory pressure $\left(\mathrm{cm} \mathrm{H}_{2} \mathrm{O}\right)$ and system tolerance. Patients were divided into two groups, depending on whether NP was normal or pathological.

Statistical analysis used the Statistical Package for Social Science (SPSS 9.0 for Windows). In the comparisons of means the Student's $t$ was used for independent variables, assessing the equality of variances with the Levene test. The level of significance was set at $\mathrm{p}<0.05$.

\section{Results}

A total of 153 patients with MO were studied, of whom 58 (38\%) were men and $95(62 \%)$ were women. In men, NP was pathological in $36(62 \%)$ and normal in $22(38 \%)$. In women, NP was pathological in 30 cases $(31 \%)$ and normal in 65 (69\%).

Men with pathological NP had older age, higher BMI (lower stature with similar weight), higher $\mathrm{W} / \mathrm{H}$ index, and higher values on the drowsiness scale than those with normal BP. Women with pathological NP had older age, weight, BMI, waist, hip, index, and diurnal drowsiness compared to those with normal NP (Table 1).

In men, according to NP results, there were no differences in blood pressure, body composition and analytical determinations, but in women there was higher SBP and baseline glycemia in the pathological NP group (Table 2).
In the respiratory functional parameters, the men with pathological NP had a lower FVC and PIM, compared to the rest. In women, there was a lower $\mathrm{PO}_{2}$ and $\mathrm{SO}_{2}$ in those with pathological NP (Tables 3,4).

In the OM and SAS groups, women were older (50 \pm 11 years), and had a higher BMI $\left(50 \pm 6 \mathrm{~kg} / \mathrm{m}^{2}\right)$ than men $(44 \pm 12$ years and $46 \pm 7$ $\left.\mathrm{kg} / \mathrm{m}^{2}\right)(\mathrm{p}<0.002$ and $\mathrm{p}<0.01$ respectively). They were also different in the type of obesity and body composition. Men had greater neck circumferences and a central predominance in obesity type, while women had higher fat mass, higher percentage of body fat and lower lean mass (Table 5). Between the two groups there were no differences in pulmonary function parameters (Table 6), but in gasometry and NP. Males had higher mean $\mathrm{PO}_{2}$ and $\mathrm{SO}_{2}$ mean diurnal, lower $\mathrm{SO}_{2}$ mean nocturnal and lower $\mathrm{SO}_{2}$ minimum nocturnal, requiring higher pressures of DPAP than females (Table 7).

\section{Discussion}

The untreated SAS has important cardio-respiratory consequences, which condition an increase in morbidity and mortality. In most SASassociated mortality studies, there is a decrease in long-term survival [20]. The most important causes in the increase of the mortality were the cardio-vascular ones [21].

The influence of obesity on the SAS is conditioned by its distribution, mainly due to its location in the upper airway (VAS). There is a greater velo-pharyngeal collapsibility in obese patients with thick necks [22]. The measurement of this fatty deposit in the VAS can be verified with dynamic NMR [23]. Thus, a good correlation $(r=0.63)$ was observed between SAS and neck circumference [24] or with the measurement of skin folds [25]. On the other hand, upper body obesity or android obesity, measured as waist-to-hip ratio, conditions a greater severity of SAS [26]. The abdominal CT scan has shown that the accumulation of visceral fat is a risk factor for SLE in obese patients [11].

These alterations in high ways occur in different ways according to sex, which would explain the different incidence of SAS in men and

Table 1. Comparisons in age, daytime sleepiness, sex and parameters anthropometric parameters and nocturnal pulse oximetry in patients with morbid obesity.

\begin{tabular}{|c|c|c|c|c|c|c|c|c|c|c|c|c|c|}
\hline NP & $\begin{array}{c}\text { Age } \\
\text { (years) }\end{array}$ & Weight(Kg) & $\begin{array}{c}\text { Height } \\
(\mathbf{c m})\end{array}$ & $\begin{array}{c}\text { BMI } \\
\left(\mathbf{K g} / \mathbf{m}^{2}\right)\end{array}$ & $\begin{array}{c}\text { Waist } \\
\text { (cm) }\end{array}$ & Hip \\
$\mathbf{( c m )}$
\end{tabular}

Values expressed as mean and standard deviation.

Table 2. Comparisons of the analytical, tensional and corporal parameters in patients with morbid obesity by sex and nocturnal pulse oximetry.

\begin{tabular}{|c|c|c|c|c|c|c|c|c|c|c|}
\hline NP & SBP & DAP & LM & FM & $\% \mathrm{BF}$ & Ht & Glyc & Ins & Chol & Tgc \\
\hline \multicolumn{11}{|l|}{ Men } \\
\hline Normal & $138(13)$ & $81(1)$ & $76(21)$ & $40(14)$ & $32(1)$ & $45(3)$ & $\begin{array}{c}91 \\
(32)\end{array}$ & $13(8)$ & $181(42)$ & $150(53)$ \\
\hline Pathological & $143(19)$ & $86(12)$ & $90(2)$ & $44(15)$ & $33(9)$ & $43(4)$ & $100(35)$ & $10(6)$ & $201(35)$ & $170(76)$ \\
\hline $\mathbf{p}<$ & 0.3 & 0.1 & 0.1 & 0.6 & 0.7 & 0.1 & 0.3 & 0.3 & 0.09 & 0.2 \\
\hline \multicolumn{11}{|l|}{ Women } \\
\hline Normal & $120(15)$ & $75(18)$ & $55(9)$ & $56(16)$ & $50(8)$ & $44(4)$ & 97 (3) & $12(6)$ & $190(37)$ & $130(48)$ \\
\hline Pathological & $136(24)$ & $80(15)$ & $64(12)$ & $66(17)$ & $50(6)$ & $40(3)$ & $118(38)$ & $14(7)$ & $194(39)$ & $\begin{array}{l}211 \\
(82)\end{array}$ \\
\hline $\mathbf{p}<$ & 0.001 & 0.1 & 0.03 & 0.07 & 0.7 & 0.4 & 0.01 & 0.3 & 0.6 & 0.1 \\
\hline
\end{tabular}

Values expressed as mean and standard deviation. 
Table 3. Diffusion of CO, muscle pressures and gasometricparameters patients with morbid obesity, according to sex and nocturnal pulse oximetry.

\begin{tabular}{|c|c|c|c|c|c|c|c|c|}
\hline NP & DLCO & KCO & PIM & PEM & pH & $\mathrm{PO}_{2}$ & $\mathrm{PCO}_{2}$ & $\mathrm{SO}_{2}$ \\
\hline \multicolumn{9}{|l|}{ Men } \\
\hline Normal & $89(15)$ & $74(12)$ & $119(31)$ & $116(36)$ & $7.41(0.02)$ & $80(1)$ & $41(5)$ & $95(2)$ \\
\hline Pathol. & $88(17)$ & $75(12)$ & $94(30)$ & $139(35)$ & $7.41(0.03)$ & $76(14)$ & $42(6)$ & $93(4)$ \\
\hline $\mathbf{p}<$ & 0.8 & 0.8 & 0.02 & 0.08 & 0.7 & 0.3 & 0.7 & 0.2 \\
\hline \multicolumn{9}{|l|}{ Women } \\
\hline Normal & $81(17)$ & $75(13)$ & $82(24)$ & $92(32)$ & $7.41(0.02)$ & $83(13)$ & $40(3)$ & $95(1)$ \\
\hline Pathol. & $84(16)$ & $76(14)$ & $71(19)$ & $86(2)$ & $7.41(0.04)$ & $71(16)$ & $43(8)$ & $92(6)$ \\
\hline $\mathbf{p}<$ & 0.6 & 0.8 & 0.1 & 0.5 & 0.9 & 0.02 & 0.1 & 0.005 \\
\hline
\end{tabular}

Values expressed as mean and standard deviation.

Table 4. Spirometric values and static volumes in patients with morbid obesity according to sex and nocturnal pulse oximetry.

\begin{tabular}{|c|c|c|c|c|c|c|c|c|}
\hline NP & DLCO & KCO & PIM & PEM & pH & $\mathrm{PO}_{2}$ & $\mathrm{PCO}_{2}$ & $\mathrm{SO}_{2}$ \\
\hline \multicolumn{9}{|l|}{ Men } \\
\hline Normal & $89(15)$ & $74(12)$ & $119(31)$ & $116(36)$ & $7.41(0.02)$ & $80(1)$ & $41(5)$ & $95(2)$ \\
\hline Pathol. & $88(17)$ & $75(12)$ & $94(30)$ & $139(35)$ & $7.41(0.03)$ & $76(14)$ & $42(6)$ & $93(4)$ \\
\hline $\mathbf{p}<$ & 0.8 & 0.8 & 0.02 & 0.08 & 0.7 & 0.3 & 0.7 & 0.2 \\
\hline \multicolumn{9}{|l|}{ Women } \\
\hline Normal & $81(17)$ & $75(13)$ & $82(24)$ & $92(32)$ & $7.41(0.02)$ & $83(13)$ & $40(3)$ & $95(1)$ \\
\hline Pathol. & $84(16$ & $76(14)$ & $71(19)$ & $86(2)$ & $7.41(0.04)$ & $71(16)$ & $43(8)$ & $92(6)$ \\
\hline $\mathbf{p}<$ & 0.6 & 0.8 & 0.1 & 0.5 & 0.9 & 0.02 & 0.1 & 0.005 \\
\hline
\end{tabular}

Values expressed as mean and standard deviation.

Table 5. Body composition in morbidly obese patients with sleep apnea syndrome according to sex.

\begin{tabular}{|c|c|c|c|c|c|c|c|}
\hline sex & neck & waist & hip & W/H & FM & LM & \%BF \\
\hline Women & $42.7(2.4)$ & $135(15)$ & $145(14)$ & $0.93(0.08)$ & $66(17)$ & $64(12)$ & $50(8)$ \\
\hline Men & $46.7(2.3)$ & $141(19)$ & $135(16)$ & $1.07(0.14)$ & $45(16)$ & $92(21)$ & $33(9)$ \\
\hline $\mathbf{p}<$ & $\mathbf{0 . 0 0 1}$ & $\mathbf{0 . 1}$ & $\mathbf{0 . 0 1}$ & $\mathbf{0 . 0 0 1}$ & $\mathbf{0 . 0 0 5}$ & $\mathbf{0 . 0 0 1}$ & $\mathbf{0 . 0 0 1}$ \\
\hline
\end{tabular}

Values expressed as mean and standard deviation.

Table 6. Differences in respiratory functional parameters between men and women with morbid obesity and sleep apnea syndrome.

\begin{tabular}{|c|c|c|c|c|c|c|c|c|}
\hline SEX & FVC & FEV $_{\mathbf{1}}$ & $\begin{array}{c}\text { FEV }_{\mathbf{1}} \text { ( } \\
\text { FVC }\end{array}$ & TLC & FRC & RV & DLCO & KCO \\
\hline Women & $100(17)$ & $99(21)$ & $84(5)$ & $97(12)$ & $73(18)$ & $85(22)$ & $82(15)$ & $74(14)$ \\
\hline Men & $95(13)$ & $91(14)$ & $79(8)$ & $95(21)$ & $72(21)$ & $91(32)$ & $90(17)$ & $77(12)$ \\
\hline p $<$ & $\mathbf{0 . 1}$ & $\mathbf{0 . 0 7}$ & $\mathbf{0 . 0 6}$ & $\mathbf{0 . 6}$ & $\mathbf{0 . 9}$ & $\mathbf{0 . 4}$ & $\mathbf{0 . 1}$ & $\mathbf{0 . 4}$ \\
\hline
\end{tabular}

Values expressed as mean and standard deviation.

Table 7. Gasometric differences and nocturnal pulse oximetry between men and women with morbid obesity and sleep apnea syndrome.

\begin{tabular}{|c|c|c|c|c|c|c|c|c|c|}
\hline SEX & $\mathbf{p H}$ & $\mathbf{P O}_{2}$ & $\mathbf{P C O}_{2}$ & $\mathbf{S O}_{2}$ & $\begin{array}{c}\text { Min } \\
\mathbf{S O}_{2}\end{array}$ & $\begin{array}{c}\text { Noct } \\
\text { SO}_{2}\end{array}$ & ODI & $\begin{array}{c}\text { Insp } \\
\text { Pres }\end{array}$ & $\begin{array}{c}\text { Expi } \\
\text { Pres }\end{array}$ \\
\hline Women & $7.41(0.03)$ & $69(13)$ & $44(8)$ & $91(6)$ & $62(12)$ & $89(7)$ & $49(33)$ & $11(3)$ & $5(1)$ \\
\hline Men & $7.41(0.02)$ & $77(13)$ & $41(6)$ & $94(3)$ & $69(14)$ & $93(3)$ & $61(39)$ & $14(4)$ & $7(2)$ \\
\hline $\mathbf{p}<$ & 0.9 & $\mathbf{0 . 0 1}$ & 0.1 & $\mathbf{0 . 0 3}$ & $\mathbf{0 . 0 5}$ & $\mathbf{0 . 0 0 4}$ & 0.1 & $\mathbf{0 . 0 0 1}$ & $\mathbf{0 . 0 0 1}$ \\
\hline
\end{tabular}

Values expressed as mean and standard deviation.

women. Thus, between 30 and 60 years the prevalence of SAS in men is $4 \%$ and in women of $2 \%$, there is a greater activity of the genioglossus muscle that dilates the upper airway, induced by progesterone [27]. There is also a different neck morphology according to sex, with differences in fat deposition in the neck with greater soft tissue in the upper airway of men [28].

Our results confirm these facts. Comparing normal and SAS men, we found a higher BMI in MO with pathological NP, at the expense of a shorter size with similar weight, as well as a waist/upper index hip. This would tell us about a different distribution of body fat, central type or android. As for body composition, there are no differences in the amount of lean mass and fat mass in these patients. It has also been shown that age is higher in patients with pathological PN, possibly because of age-dependent development of a type of central obesity.

As for women is the total weight, both fat mass and lean mass, regardless of height, which conditions a pathological NP. Although both the hip and waist circumference are superior, in the pathological, an android type distribution is maintained. Likewise, the age is higher, perhaps due to the higher prevalence of SAS in postmenopausal women [29] whose hormonal changes would lead to a greater distribution of central type fat, as has already been demonstrated in other studies [26].

We have verified, in patients with MO and SAS a wider neck in men, with an android type corporal distribution in them. In contrast, women with SAS and MO are older than men, they have more BMI at the expense of greater fat mass and percentage of body fat and have lower lean mass.

On the other hand, we have seen a higher SBP in women with pathological NP as well as superior basal glycemia, in concordance with studies associating SAS with arterial hypertension and elevated insulin resistance [25]. However, in men we have not checked these differences.

In addition to cardiovascular risk, nocturnal respiratory changes condition lower quality of life. Thus, we have seen, in men as well as in women, greater daytime sleepiness, which sometimes becomes invalidating regarding the difference of the respiratory parameters between MO with or without SAS, differences have been described. On the one hand, there is a $50 \%$ hypercapnia $\left(\mathrm{PCO}_{2}>42 \mathrm{mmHg}\right)$, conditioned by lower VC, TLC and $\mathrm{FEV}_{1}$ [30]. On the other hand, the decrease in VC in patients with SAS is associated with hypertension and central type obesity. In moderately obese patients, those with SAS have lower $\mathrm{FEV}_{1}, \mathrm{FVC}$, TLC and $\mathrm{PO}_{2}$ and higher $\mathrm{PCO}_{2}$ than control [31]. The presence of SAS in MO induces greater diurnal hypoxemia [32]. The FRC has shown a negative correlation with the ODI [33]. As for diffusion, an increase in DLCO and KCO has been reported in the obese with SAS, which correlates more with BMI than with SAS itself [35].

Our data provide different behavior in respiratory functional tests according to sex. While in men with SAS and OM we detected a lower 
FVC and PIM, in women the functional parameters were similar, with a decrease in $\mathrm{PO}_{2}$ and in Sat. of $\mathrm{O}_{2}$. These differences would be justified by their different degree and type of obesity. Comparing men and women with $\mathrm{MO}$ and SAS, there are no differences in respiratory functional parameters, but we have observed a lower $\mathrm{PO}_{2}$ and Sat. of $\mathrm{O}_{2}$ in women, although men with SAS and MO have a Sat. $\mathrm{O}_{2}$ lower, requiring higher pressures of BiPAP with similar ODI. These data coincide with other studies that demonstrate that, in $\mathrm{MO}$, men have a higher severity of nocturnal respiratory disorders [36].

The treatment of MO can improve SAS and the respiratory and gasometric parameters $[37,38]$. This SAS resolution with weight loss is associated with a decrease in the collapsibility of the upper airway [39] with an improvement in glottal and pharyngeal function [40]. However, SAS may reappear if there is a new weight gain [41], or even without an increase in weight [42]. This indicates that the overweight is not the only pathogenic factor of the SAS, the anatomic-functional situation of the upper airway being more important.

We conclude that nocturnal respiratory alterations may occur more frequently in men than in women, which cause greater daytime sleepiness. These alterations occur in patients with older and higher $\mathrm{BMI}$ and an android type obesity. In males, they will produce decreased FVC and PIM and in women diurnal hypoxemia and higher basal glycemia and SAD levels.

\section{References}

1. Strohl KP, Redline S (1996) Recognition of obstructive sleep apnea. Am J Respir Crit Care Med 154: 279-289. [Crossref]

2. Stradling JR (1995) Obstructive sleep apnoea: definitions, epidemiology, and natural history. Thorax 50: 683-689. [Crossref]

3. Shepard JW (1992) Hypertension, cardiac arrhythmias, myocardial infarction, and stroke in relation to obstructive sleep apnea.Clin Chest Med 13 : 437-458. [Crossref]

4. Lavie P, Herer P, Peled R, Berger I, Yoffe N, et al. (1995) Zomer J, Rubin AH. Mortality in sleep apnea patients: a multivariate analysis of risk factors. Sleep 18: 149157. [Crossref]

5. Alpert MA, Hashimi MW (1993) Obesity and the heart. Am J Med Sci 306: 117-123. [Crossref]

6. Krachman S, Criner GJ (1998) Hypoventilation syndromes. Clin Chest Med 19: 139155. [Crossref]

7. Kyzer S, Charuzi I (1998) Obstructive sleep apnea in the obese. World J Surg 22: 9981001. [Crossref]

8. Vgontzas AN, Tan TL, Bixler EO, Martin LF, Shubert D, et al. (1994) Sleep apnea and sleep disruption in obese patients. Arch Intern Med 154: 1705-1711. [Crossref]

9. Rössner S, Lagerstrand L, Persson HE, Sachs C (1991) The sleep apnoea syndrome in obesity: risk of sudden death. J Intern Med 230: 135-141. [Crossref]

10. Rajala R, Partinen M, Sane T, Pelkonen R, Huikuri K, et al. (1991) Obstructive sleep apnoea syndrome in morbidly obese patients. J Intern Med 230: 125-129. [Crossref]

11. Shinohara E, Kihara S, Yamashita S, Yamane M, Nishida M, et al. (1997) fat accumulation as an important risk factor for obstructive sleep apnoeaSyndrome in obese subjects. J Intern Med 241: 11-18. [Crossref]

12. Sociedad Española para el Estudio de la Obesidad (SEEDO) (2000) Consenso SEEDO'2000 para la evaluación del sobrepeso y la obesidad y el establecimiento de criterios de intervención terapéutica. Med Clin (Barc) 115: 587-597.

13. American Thoracic Society.Single-breath carbon monoxide diffusing capacity (transfer factor): recomendationfor a estándar technique-1995 update. (1995) Am J Respir Crit Care Med 152: 2185-2198. [Crossref]

14. Black LF, Hyatt RE (1969) Maximal respiratory pressure: normal values and relationship to age and sex.Am Rev Respir Dis 99: 969-702. [Crossref]
15. Quanjer PH (1983) Standardized lung function testing. Bull Eur Physiopathol Respir 5: 1-95. [Crossref]

16. Morales P, Sanchis J, Cordero PJ, Díez JL (1997) [Maximum static respiratory pressures in adults. The reference values for a Mediterranean Caucasian population]. Arch Bronconeumol 33: 213-219. [Crossref]

17. Johns MW (1991) A new method for measuring daytime sleepiness: the Epworth sleepiness scale. Sleep 14: 540-545. [Crossref]

18. Ferrer M, Vilagut G, Monasterio C, Montserrat JM, Mayos M, et al. (1999) Medida del impacto de los trastornos del sueño: las versiones españolas del cuestionario del impacto funcional del sueño y de la escala de somnolencia de Epworth. Med Clin (Barc) 113: 250-255

19. Tremper KK (1989) Pulse oximetry. Chest 95: 713-715. [Crossref]

20. Partinen M, Hever P, Jamieson A, Guilleminault CG (1988) Long-term outcome for obstructive sleep apnea syndrome patients: mortality. Chest 94: 9-14. [Crossref]

21. Partinen M, Guilleminault C (1990) Daytime sleepiness and vascular morbidity a seven-year follow-up in obstructive sleep apnea patients. Chest 97: 27-32. [Crossref]

22. Ryan CF, Love LL (1996) Mechanical properties of the velopharynx in obese patients with obstructive sleep apnea.Am J Respir Crit Care Med 154: 806-812. [Crossref]

23. Shelton KE, Woodson H, Gay S, Suratt PM (1993) Pharyngeal fat in obstructive sleep apnea. Am Rev Respir Dis 148: 462-466. [Crossref]

24. Davies RJ, Stradling JR (1990) The relationship between neck circumference, radiographic pharyngeal, anatomy,and the obstructive sleep apnea syndrome. Eur Respir J 3: 509-514. [Crossref]

25. Levinson PD, McGarvey ST, Carlisle CC, Eveloff SE, Herbert PN, et al. (1993) Adiposity and cardiovascular risk factors in men with obstructive sleep apnea. Chest 103: 1336-1342. [Crossref]

26. Millman RP, Carlisle CC, McGarvey ST, Eveloff SE, Levinson PD (1995) Body fat distribution and sleep apnea severity in women. Chest 107: 362-366. [Crossref]

27. Schwab J (1999) Sex differences and sleep apnoea. Thorax 54: 284-285. [Crossref]

28. Whittle AT, Marshall I, Mortimore IL, Wraith PK, Sellar RJ, et al. (1999) Neck soft tissue and fat distribution: comparison between normal men and women by magnetic resonance imaging. Thorax 54: 323-328. [Crossref]

29. Gislason T, Benediktsdóttir B, Björnsson JK, Kjartansson G, Kjeld M, et al. (1993) Snoring, Hypertension, and the Sleep Apnea Syndrome.An Epidemiologic Survey of Middle-aged Women. Chest 103: 1147-1151. [Crossref]

30. Laaban JP, Orvoen-Frija E, Cassuto D, Pascal S, Leger D, et al. (1996) Mechanisms of diurnal hypercapnia in sleep apnea syndromes associated withMorbid obesity. Presse Med; 25: 12-6. [Crossref]

31. Kiselak J, Clark M, Pera V, Rosenberg C, Redline S (1993) The association between hypertension and sleep apnea in obese patients. Chest 104: 775-780. [Crossref]

32. Gold AR, Schwartz AR, Wise RA, Smith PL (1993) Pulmonary function and respiratory chemosensitivity in moderately obese patients with sleep apnea. Chest 103: 1325-1329. [Crossref]

33. Laaban JP, Cassuto D, Orvoën-Frija E, Iliou MC, Mundler O, et al. (1998) Cardiorespiratory consequences of sleep apnoea syndrome in patients with massive obesity. Eur Respir J 11: 20-27. [Crossref]

34. Onal E, Leech JA, Lopata M. (1985) Relationship between pulmonary function and sleep-induced respiratory abnormalities. Chest 87: 437-441.

35. Collard P, Wilputte JY, Aubert G, Rodenstein DO, Frans A (1996) The single-breath diffusing capacity for carbon monoxide in obstructive sleep apnea and obesity. Chest 110: 1189-1193. [Crossref]

36. van Boxem TJ, de Groot GH (1999) Prevalence and severity of sleep disordered breathing in a group of morbidly obese patients. Neth J Med 54: 202-206. [Crossref]

37. Sugerman HJ, Fairman RP, Baron PL, Kwentus JA (1986) Gastric surgery for respiratory insufficiency of obesity. Chest $90: 81-86$. [Crossref]

38. Boone KA, Cullen JJ, Mason EE, Scott DH, Doherty C, et al. (1996) Impact of Vertical Banded Gastroplasty on Respiratory Insufficiency of Severe Obesity. Obes Surg 6 : 454-458. [Crossref] 
39. Schwartz AR, Gold AR, Schubert N, Stryzak A, Wise RA, et al. (1991) Effect of weight loss on upper airway collapsibility in obstructive sleep apnea. Am Rev Respir Dis 144: 494-498. [Crossref]

40. Rubinstein I, Colapinto N, Rotstein LE, Brown IG, Hoffstein V (1988) Improvement in upper airway function after weight loss in patients with obstructive sleep apnea. $A m$ Rev Respir Dis 138: 1192-1195. [Crossref]
41. Charuzi I, Lavie P, Peiser J, Peled R (1992) Bariatric surgery in morbidly obese sleep-apnea patients: short- and long-term follow-up. Am J Clin Nutr 55: 594S-596S. [Crossref]

42. Pillar G, Peled R, Lavie P (1994) Recurrence of sleep apnea without concomitant weight increase 7.5 years after weight reduction surgery. Chest 106: 1702-1704. [Crossref]

Copyright: $\mathbb{C} 2017$ Silvestre AH. This is an open-access article distributed under the terms of the Creative Commons Attribution License, which permits unrestricted use, distribution, and reproduction in any medium, provided the original author and source are credited. 